\title{
First Report of an Unrecorded Nematode-Trapping Fungus Species Monacrosporium phymatopagum in Korea
}

\author{
Hai-Yan $\mathrm{Wu}^{1}$ and Dong-Geun $\mathrm{Kim}^{2 *}$ \\ ${ }^{1}$ College of Plant Protection, Shandong Agricultural University, Tai'an 271018, China \\ ${ }^{2}$ Institute for Natural Products Research, Gyeongbuk Agricultural Technology Administration, Sangri-ri 133-6, Euiseong, Korea \\ (Received on June 12, 2010; Accepted on August 6, 2010)
}

\begin{abstract}
A fungus that can capture nematodes by means of sessile adhesive knobs was isolated from rotten wood in Uiseong, Korea. It was found to produce single, spindleshaped, 3-4 septate (commonly 4-septate) conidia, 44.8 $\mu \mathrm{m}$ (range, 41.6-50.1 $\mu \mathrm{m}$ ) long and $13.3 \mu \mathrm{m}$ (range, 10.7$15.4 \mu \mathrm{m})$ wide. Conidiophores were found to be hyaline, erect, straight, and 202.7-245.7 $\mu \mathrm{m}$ high. On the basis of these morphological features, the fungus was identified as Monacrosporium phymatopagum. This is the first report of $M$. phymatopagum in Korea which can be a potential biological control resource of plant parasitic nematode.
\end{abstract}

Keywords: Monacrosporium phymatopagum, nematodetrapping, sessile knob, unrecorded species

During a survey of bio-control fungi of plant parasitic nematode in Korea in 2009, rotten wood was sampled, crushed, and screened through a 1-mm-diameter testing sieve. A modified sprinkling-baiting technique was used to isolate nematode-trapping fungi (Barron, 1977). Rotten wood powder (approximately $0.5 \mathrm{~g}$ ) was sprinkled onto a plate containing both $1.7 \%$ corn meal agar (CMA; Difco) and 2\% water agar (WA), and approximately 200 nematodes (Rhabditis spp.) were added to the surface of a petri dish (diameter, $10 \mathrm{~cm}$ ) as bait for the nematode-trapping fungi. Two CMA plates and 2 WA plates were used for each sample. The plates were incubated for 2-4 weeks at $25^{\circ} \mathrm{C}$ and were examined every other day under a dissecting microscope (Olympus $\mathrm{SZ} \times 12$ ) to detect the appearance of nematode-trapping fungi. When nematode-trapping fungus was detected, it was photographed using an attached digital camera (Nikon DXM1200F) and was transferred to a CMA plate for pure culture. A nematode-trapping fungus that was identified as Monacrosporium phymatopagum was isolated; this species has not been reported in Korea to date. A description of the species is presented in this paper. The

\footnotetext{
*Corresponding author.

Phone) +82-54-832-9669, FAX) +82-54-833-1359

E-mail)kimdgkr@naver.com
}

taxonomic changes of the species are as follows:

Monacrosporium phymatopagum (Drechsler) Subram., J. Indian Bot. Soc. 42: 293. 1963.

= Dactylella phymatopaga Drechsler, Mycologia 46: 775 . 1954

= Golovinia phymatopaga (Drechsler) Mekht., Khishchnye nematofogovye Griby-Gifomitsety: 165. 1979

= Gamsylella phymatopaga (Drechsler) M. Scholler, Sydowia 51: 109. 1999.

This species was originally described by Charles Drechsler (1954) after isolation from decaying vegetable material collected in southern Louisiana on Dec. 20, in 1952 and cultured on a corn meal agar (CMA) plate. The mycelial growth in this species is often scanty, and the mycelia consist of colorless, branched vegetative hyphae that are septate at moderate intervals, often (especially in the presence of nematodes) bearing adhesive protuberances at intervals of 5-125 $\mu \mathrm{m}$ (mostly at intervals of 10-50 $\mu \mathrm{m}$ ). The adhesive protuberances are sessile, obovoid or prolate ellipsoid, and are 6.0-9.5 $\mu \mathrm{m}$ long, 2-3 $\mu \mathrm{m}$ wide at the base, and 3.8-5.5 $\mu \mathrm{m}$ at the greatest width, and are usually filled with homogeneous contents at the base and granular protoplasm the distal region. The conidiophores are colorless, erect, 250-325 $\mu \mathrm{m}$ in height, 3.5-4.5 $\mu \mathrm{m}$ wide at the base, and gradually taper upward to about $2 \mu \mathrm{m}$ at the tip where a single conidium is borne. The conidia are colorless, typically spindle-shaped, truncate, quite narrow at the base, rounded at the distal end, mostly 40-60 $\mu \mathrm{m}$ (average, 49.2 $\mu \mathrm{m}$ ) in length, and 11-18 $\mu \mathrm{m}$ (average, $14.4 \mu \mathrm{m}$ ) wide. The conidia are commonly divided by 4 cross-walls into 5 cells, of which the middle cell usually exceeds the others in length and width.

We isolated $M$. phymatopagum for the first time in Korea. The fungus produces spindle-shaped, 2-4 septate conidia (2-septate, $2 \%$, 3-septate, $12 \%$, and 4-septate $86 \%$ in 50 conidia counts) on CMA, $44.8 \mu \mathrm{m}$ (range, 41.6-50.1 $\mu \mathrm{m}$ ) long, and $13.3 \mu \mathrm{m}$ (range, 10.7-15.4) $\mu \mathrm{m}$ wide (Fig. 1A, B). Adhesive sessile knobs, instead of stalked knobs, to capture nematodes are a distinct feature of $M$. phymatopagum (Fig. 1E). The sessile knobs are produced either in the presence of nematodes or on CMA medium (Fig. 1C, D). In aged 30- 

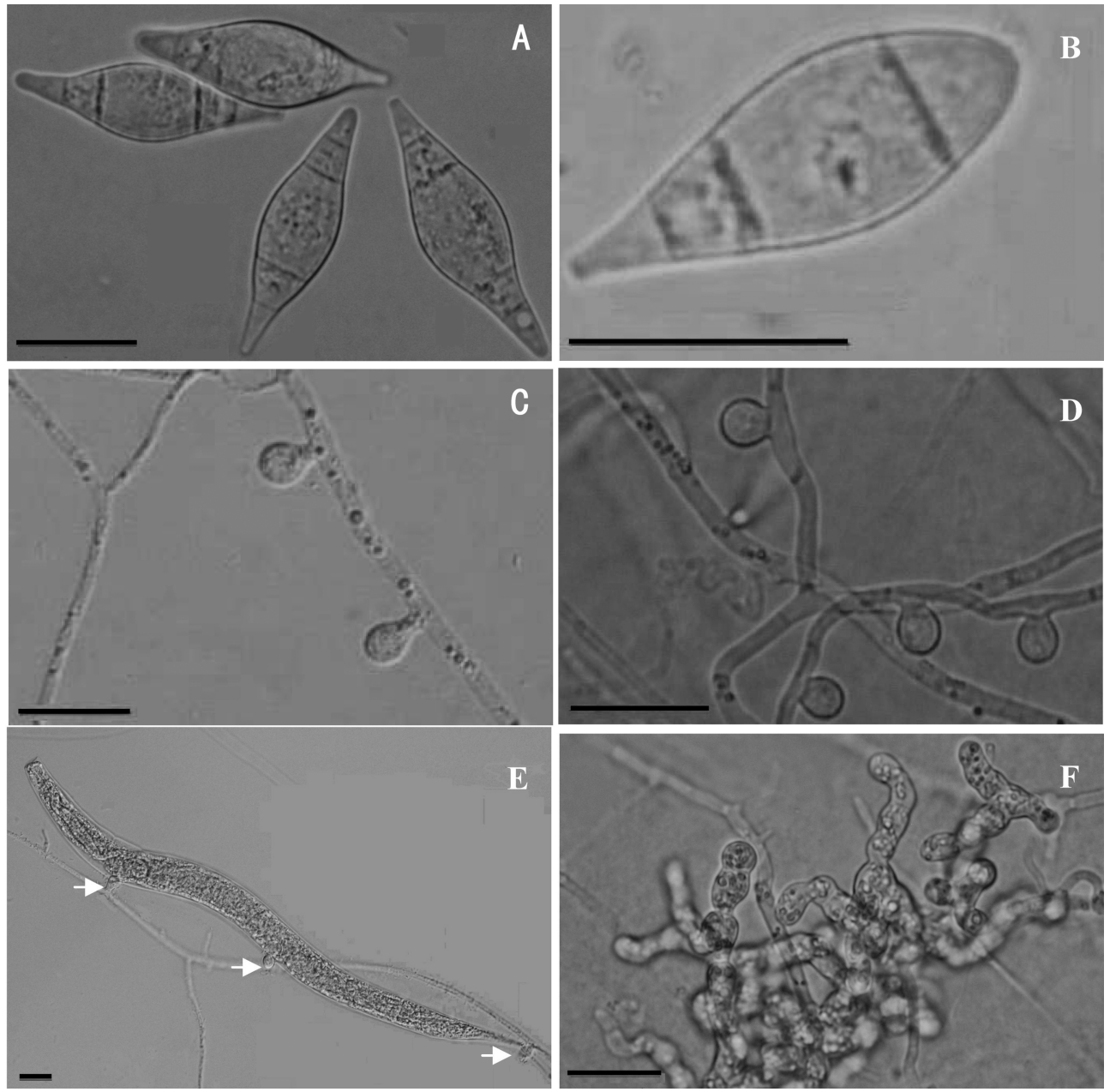

$\mathbf{E}$

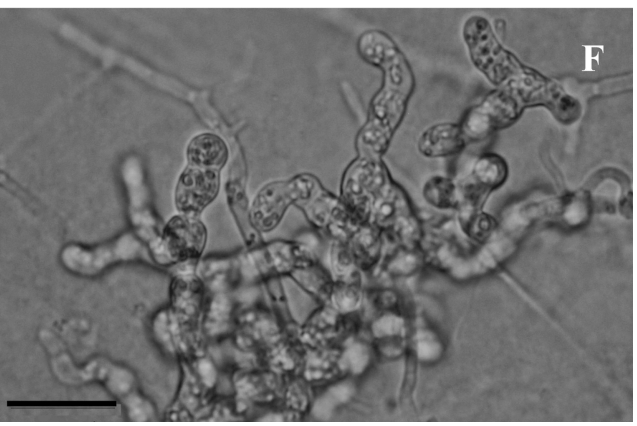

Fig. 1. Monacrosporium phymatopagum. A, B. Conidia, C. Adhesive sessile knob produced from nematodes-infested water agar medium, D. Adhesive sessile knob produced from pure CMA, E. Nematode fast held by adhesive knob (the knobs indicated by arrows), F. Distended storage hyphae filled with protoplasm produced on CMA. Bars $=200 \mu \mathrm{m}$.

Table 1. Comparison of the Monacrosporium phymatopagum isolates from Korea with the original description and other closely related species (Drechsler, 1954, 1961; McCulloch, 1977)

\begin{tabular}{|c|c|c|c|c|c|}
\hline \multicolumn{2}{|c|}{ Character } & \multirow{2}{*}{$\begin{array}{c}\text { Korea isolate } \\
210.7-283.2\end{array}$} & \multirow{2}{*}{$\begin{array}{l}\text { Original description } \\
\text { Commonly } 250-325\end{array}$} & \multirow{2}{*}{$\begin{array}{c}\text { M.parvicollis } \\
130-290\end{array}$} & \multirow{2}{*}{$\begin{array}{c}\text { M. robustum } \\
150-450\end{array}$} \\
\hline Conidiophores & Length $(\mu \mathrm{m})$ & & & & \\
\hline \multirow{3}{*}{ Conidia } & Length $(\mu \mathrm{m})$ & $41.6-50.1$ & $40.0-60.0$ & $35.0-45.0$ & $68.0-85.0$ \\
\hline & Width $(\mu \mathrm{m})$ & $12.5-15.4$ & $11.0-18.0$ & $8.0-14.0$ & $20.0-30.0$ \\
\hline & Septa & Commonly 4 & Commonly 4 & 2-4, Mostly 4 & $3-5$ \\
\hline \multirow{4}{*}{ Adhesive knob } & Length $(\mu \mathrm{m})$ & $\begin{array}{l}5.5-9.6^{\mathrm{a}} \\
5.7-7.3^{\mathrm{b}}\end{array}$ & $6.0-9.5$ & $6.5-11.0$ & $16.0-24.0$ \\
\hline & Width $(\mu \mathrm{m})$ & $\begin{array}{l}4.7-6.1^{\mathrm{a}} \\
4.8-6.2^{\mathrm{b}}\end{array}$ & $3.8-5.5$ & $5.5-9.0$ & $9.0-10.0$ \\
\hline & Stalk $(\mu \mathrm{m})$ & No & No & No or short stalk & No \\
\hline & Shape & $\begin{array}{l}\text { Globose, obovoid } \\
\text { or prolate ellipsoid }\end{array}$ & $\begin{array}{l}\text { Obovoid or prolate } \\
\text { ellipsoid }\end{array}$ & $\begin{array}{l}\text { Globose, obovoid or } \\
\text { prolate ellipsoid }\end{array}$ & Prolate ellipsoid \\
\hline
\end{tabular}

${ }^{\mathrm{a}} \mathrm{WA}+$ nematode; ${ }^{\mathrm{b}} \mathrm{CMA}$. 
day-old cultures, some distended storage hyphae filled with protoplasm appeared (Fig. 1F) - also one of the characteristics of $M$. phymatopagum (Drechsler, 1954). The $M$. phymatopagum isolates were consistent with the original description by Drechsler (Table 1), except for a few differences: the conidiophores were shorter and the knobs larger. The M. phymatopagum isolate was deposited at the Institute for Natural Products Research, Gyeongbuk Agricultural Technology Administration.

M. phymatopagum can be distinguished from several other nematode-trapping fungi, which have stalked adhesive knobs, by its sessile adhesive knobs. Another nematodetrapping fungus, Monacrosporium robustum, also has sessile knobs for capturing nematodes; however, this species has large conidia, (68.0-85.0 $\mu \mathrm{m}$ long and 20-30 $\mu \mathrm{m}$ wide), which are clearly distinct from those of M. phymatopagum. Another closely related fungus Monacrosporium parvicollis produces adhesive knobs on relatively short, yet clearly recognizable stalks (Table 1). These short stalks have never been observed in the adhesive knobs of M. phymatopagum. Recently, Li et al. (2005) reviewed species of Monacrosporium and proposed transferring M. phymatopagum to Dactylellina phymatopaga on the basis of phylogenetic interpretation.

In Korea, the nematode-trapping fungi Arthrobotrys (8 species: Arthrobotrys amerospora, A. arthrobotryoides, $A$. brochopaga, A. conoides, A. dactyloides, A. musiformis, $A$. oligospora, A. vermicola), Monacrosporium (5 species: Monacrosporium cionopagum, M. ellipsosporum, M. gephyropagum, M. thaumasium, M. ullum), and Dactylella (2 species: Dactylella lobata, D. pseudoclavata) have been reported. This is the first report of the isolation of the unrecorded nematode-trapping fungus species M. phymatopagum in Korea.

\section{Acknowledgements}

This study was sponsored by the Korean-China Scientist (Post-doc.) Exchange Program and the Public Industry (Agriculture) Specific Research Program of China (200903040).

\section{References}

Barron, G. L. 1977. Tropics in Mycobiology No.. Nematodedestroying fungi. Lancaster Press, Inc., Lancaster Pennsylvania. $140 \mathrm{pp}$.

Drechsler, C. 1954. Some hyphomycetes that capture eelworms in Southern States. Mycologia 46:762-782.

Drechsler, C. 1961. Some clampless hyphomycetes predaceous on nematodes and rhizopods. Sydowia 15:9-25.

Li, Y., Hyde, K. D., Jeewon, R., Cai, L., Vijaykrishna, D. and Zhang, K. 2005. Phylogenetics and evolution of nematodetrapping fungi (Orbiliales) estimated from nuclear and protein coding genes. Mycologia 97:1034-1046.

McCulloch, J. S. 1977. New species of nematophagous fungi from Queensland. Trans. Br. Mycol. Soc. 68:173-179.

Mekhtieva, N. A. 1979. Khishchnye Nematofagovye Griby-Gifomitsety [Predacious nematophagous hyphomycetes]. Akademiya Nauk Azerbaidzhanskoi SSR, Baku. 165 pp.

Scholler, M., Hagedorn, G. and Rubner, A. 1999. A reevaluation of predatory orbiliaceous fungi. II. A new generic concept. Sydowia 51:89-113.

Subramanian, C. V. 1963. Dactylella, Monacrosporium and Dactylina. J. Indian Bot. Soc. 42:291-300. 